\title{
The resistance of the mouse uterine lumen to flushing and possible contamination of samples by plasma and interstitial fluid
}

\author{
S. R. Milligan and L. Martin*† \\ Department of Physiology, King's College, Strand, London WC2R $2 L S$ and ${ }^{*}$ Department of \\ Hormone Physiology, Imperial Cancer Research Fund, Lincoln's Inn Fields, London WC2A 3PX, \\ U.K.
}

\begin{abstract}
Summary. The hydrostatic pressures generated during controlled flushing of the mouse uterus increased at implantation and under conditions of uterine closure. These pressures may be responsible for inducing tissue damage during flushing. The possibility that samples collected by flushing might be contaminated with interstitial fluid or plasma was studied using intravenously administered ${ }^{51} \mathrm{Cr}$-labelled EDTA and ${ }^{25}$ I-labelled human serum albumin as markers. The presence of both tracers was detected in all flushings and was greatest in flushings from uteri with luminal closure and early implantation sites. These observations raise serious doubts about the validity of the flushing technique for analysing uterine luminal constituents in mice.
\end{abstract}

\section{Introduction}

The technique of collecting flushings from the lumen of the uterus has been used extensively in the mouse to study qualitative and quantitative changes in protein secretion in different reproductive states and during early pregnancy (e.g. Aitken, 1977a, b; Pratt, 1977; Guise, Gwazdauskas \& Lineweaver, 1981; Hoversland \& Weitlauf, 1982). Particular attention has focussed on the changes in uterine luminal proteins occurring at implantation (e.g. Aitken, 1977a; Pratt, 1977). At this time, however, the volume of the uterine lumen is dramatically reduced by the close apposition of the opposing epithelial walls (Martin \& Finn, 1970). This 'closure' of the lumen raises the question of the source of the 'luminal' constituents: do they really represent material in the essentially nonexistent lumen, or are they the result of tissue damage and leaching caused by the attempt to flush the 'closed' lumen? Martin (1984) has reported that flushing may split the epithelium and rupture the underlying stroma and blood vessels, with maximal damage occurring when the uterus exhibits closure and contains early implantation sites. Subjective observations suggested that flushing of 'closed' uteri required greater force and this would be consistent with the greater likelihood of inducing tissue damage. This study was undertaken to provide a quantitative basis for the subjective observations on the resistance of the uterus to flushing. The possible contamination by plasma and interstitial fluid of samples collected by uterine flushing was investigated by using radiolabelled tracers as markers for these fluids.

† Present address : Department of Physiology and Pharmacology, University of Queensland, St Lucia, Queensland 4067, Australia.

(C) 1984 Journals of Reproduction \& Fertility Ltd 


\section{Materials and Methods}

Animals. In Exp. 1, randomly bred Swiss Schneider mice were housed as described by Martin \& Finn (1979). In Exps 2 and 3, albino Swiss mice (A. Tuck \& Son, Ltd) were housed as described by Milligan \& Lytton (1983). The timing of events in pregnancy was taken from the day of finding the vaginal plug (Day 1). On this basis, uterine closure begins on Day 4 of pregnancy and implantation sites ('pontamine blue spots') become visible on Day 5 (Martin, 1980). Females on Day 5 of pregnancy were injected with $0.1 \mathrm{ml} 2 \%$ Pontamine Sky Blue $15 \mathrm{~min}$ before death to check for implantation sites. Ovariectomies were performed using tribromoethanol anaesthesia and ovariectomized, non-pregnant females were left for at least 2 weeks before further treatment. Ovariectomized females were generally primed with 2 daily injections of $100 \mathrm{ng}$ oestradiol-17 $\beta$ followed 3 days later by daily injections of $1 \mathrm{mg}$ progesterone alone, or $1 \mathrm{mg}$ progesterone $+10 \mathrm{ng}$ oestradiol-173. These steroids (Sigma London Chemical Co. Ltd, Poole, U.K.) were given subcutaneously in $0.1 \mathrm{ml}$ arachis oil (British Drug Houses Ltd, Poole, U.K.). Limited uterine closure occurs after 4 days of progesterone treatment alone, but full closure occurs in females treated for 4 days with progesterone and oestradiol (Pollard \& Finn, 1972). Injections of medroxyprogesterone acetate (Sigma) were given as a suspension in $0 \cdot 1 \mathrm{ml} 0 \cdot 154 \mathrm{M}-\mathrm{NaCl}$.

Experiment 1: the hydrostatic pressures generated during controlled uterine flushing. Uteri were subject to flushing for $30 \mathrm{sec}$ at a controlled rate of $300 \mu \mathrm{l} / \mathrm{min}$ using an infusion pump (Scientific and Research Instruments Ltd, Edenbridge, U.K.). The hydrostatic pressure during flushing was monitored by a pressure transducer (Type 4-422; Bell \& Howell Ltd, Basingstoke, U.K.) connected to a side arm of the infusion system and was recorded on a pen recorder (Devices Ltd). Flushings were performed on the uteri from (a) ovariectomized females given: (i) no steroid treatment; (ii) $100 \mathrm{ng}$ oestradiol- $17 \beta$ daily for 2 days; (iii) 2 days of priming with $100 \mathrm{ng}$ oestradiol-17 $\beta$, followed 3 days later by 4 daily injections of $1 \mathrm{mg}$ progesterone or (iv) $1 \mathrm{mg}$ progesterone and $10 \mathrm{ng}$ oestradiol$17 \beta$, and (b) intact females on (i) Day 4 and (ii) Day 5 of pregnancy. Females were killed by cervical dislocation between 11:00 and 15:00 h. Each uterine horn was quickly dissected out, with care being taken to limit handling to the extreme tips of the horns. The uterine horns were placed on a Petri dish on ice and the oviducal tips transected to facilitate access to the lumen. A blunt 25 -gauge needle was inserted into the oviducal end of each horn and was held in position with fine forceps. The flushing medium was $0.154 \mathrm{M}-\mathrm{NaCl}$ containing $0.1 \%$ Pontamine Sky Blue to facilitate observation.

Experiments 2 and 3 : contamination of uterine flushings by plasma and interstitial fluid. Intravenously injected ${ }^{51} \mathrm{Cr}$-labelled EDTA (Amersham International Ltd, U.K.; 7-15 $\mu \mathrm{Ci}$ in $0.15 \mathrm{ml} 0.154 \mathrm{M}$ $\mathrm{NaCl}$; sp. act. 1-2 mCi/mg Cr) and ${ }^{125} \mathrm{I}$-labelled human serum albumin (Amersham: $5 \mu \mathrm{Ci}$ in $0 \cdot 1$ $\mathrm{ml} 0.154 \mathrm{M}-\mathrm{NaCl} ; 20 \mathrm{mg}$ albumin/ml) were used as markers for interstitial fluid and plasma respectively. Renal clearance of ${ }^{51} \mathrm{Cr}$-labelled EDTA was prevented by ligation of the renal pedicle. Preliminary studies indicated that a circulation time of $30 \mathrm{~min}$ for ${ }^{51} \mathrm{Cr}$-labelled EDTA was more than sufficient to allow equilibration of this extracellular marker $\left(M_{r} 341\right)$ within uterine tissue. ${ }^{125}$ I-labelled HSA diffuses out of the circulation much more slowly and Sassen, Reuter \& Kennes (1968) estimated that little extravascular leakage occurred in the mouse uterus within a circulation time of $3 \mathrm{~min}$. In the present study, flushings from the uterine lumen were obtained after the intravenous administration of ${ }^{51} \mathrm{Cr}$-labelled EDTA and ${ }^{125} \mathrm{I}$-labelled HSA $30 \mathrm{~min}$ and $3 \mathrm{~min}$ earlier respectively. Mice were anaesthetized with pentobarbitone sodium (Sagatal: May \& Baker, Ltd, Dagenham, U.K.; diluted 1:5 with $0.154 \mathrm{M}-\mathrm{NaCl} ; 0.1 \mathrm{ml}(1.0 \mathrm{mg})$ administered/10 g body weight), the renal pedicles were ligated and the isotopic tracers were then injected into the external jugular vein at the appropriate time before the animal was killed by cervical dislocation. The plasma concentrations of ${ }^{51} \mathrm{Cr}$-labelled EDTA and ${ }^{125} \mathrm{I}$-labelled HSA were estimated from a terminal blood sample obtained by cardiac puncture. Since ${ }^{51} \mathrm{Cr}$-labelled EDTA distributes in extracellular space, the plasma concentration of ${ }^{51} \mathrm{Cr}$-labelled EDTA also provided an estimate of 
its concentration in interstitial fluid. The uterine horns were rapidly removed, cleared of adhering mesentery, blotted gently to remove excess blood, rinsed in $0 \cdot 154 \mathrm{M}-\mathrm{NaCl}$ and blotted gently again. Each uterine horn was flushed from the oviducal end with $0.5 \mathrm{ml} 0.154 \mathrm{M}-\mathrm{NaCl}$ delivered over 3-4 sec from a hand-held syringe through a sharp 25-gauge needle. In Exp. 3 (ii) and (iv), an infusion pump (Scientific \& Research Instruments Ltd) was used to deliver $150 \mu$ l saline through a blunt $30-$ gauge needle at a controlled rate of $300 \mu \mathrm{l} / \mathrm{min}$. All flushings were collected in clean plastic tubes. The concentration of ${ }^{51} \mathrm{Cr}$-labelled EDTA and trichloracetic acid-precipitable ${ }^{125}$ I-labelled HSA in $100 \mu \mathrm{l}$ plasma and in each uterine flushing was measured using a Nuclear Enterprises automatic gamma counter (Model 8311). The estimates of the contamination of the flushings by plasma and interstitial fluid were based on all radioactivity in the flushings being derived from these sources and the results were expressed in terms of the volume $(\mathrm{nl})$ of either fluid containing the equivalent amount of tracer.

In Exp. 2, uterine flushing was performed on: (i) untreated ovariectomized females; and ovariectomized females primed with oestradiol and treated with (ii) progesterone and oestradiol for 2 days, (iii) progesterone and oestradiol for 4 days, or (iv) progesterone alone for 4 days.

In Exp. 3, uterine flushing was performed on mated females on Day 3 and 5 of pregnancy using either the manual flushing technique (Treatments (i) and (iii), respectively), or slow, controlled flushing from an infusion pump (Treatments (ii) and (iv), respectively). Uterine flushing was also performed on females ovariectomized on Day 3 of pregnancy and treated with $1 \mathrm{mg}$ medroxyprogesterone acetate to delay implantation (Yoshinaga \& Adams, 1966): flushing was carried out on Day 10 after (v) no further treatment, or (vi) 50 ng oestradiol-17 7 on Day 9 to induce implantation (Humphrey, 1967).

Statistical analysis. Results were analysed by Students' unpaired $t$ test or analysis of variance followed by Duncan's New Multiple Range test (Li, 1957) as appropriate.

\section{Results}

\section{Experiment 1: hydrostatic pressures generated during controlled uterine flushing}

The recordings of the hydrostatic pressures generated during the uterine flushings showed qualitative and quantitative differences between treatments. In untreated, ovariectomized females and oestrogen-treated females, the pressures generated were low and either remained steady or declined slowly during the flushing. In contrast, in females exposed to progesterone, the pressures usually rose rapidly to a sharp peak at the start of the flushing. Direct observation of the uteri during flushing showed that this peak pressure was associated with the initial passage of the flushing medium into and along the uterus. Once the front of the fiushing fluid reached the distal end of the uterus, the pressure fell immediately and remained at a lower steady level. The peak pressures generated during flushing are given in Table 1 . In ovariectomized females, the pressures were highest in uteri from females treated with progesterone and oestradiol to induce full uterine closure. In pregnant females, the pressures generated during flushing uteri on Day 5 (with implantation sites) were significantly higher than on Day 4 (before implantation).

\section{Experiments 2 and 3: contamination of uterine flushings by plasma and interstitial fluid}

All uterine flushings contained some ${ }^{51} \mathrm{Cr}$-labelled EDTA and ${ }^{125} \mathrm{I}$-labelled HSA (Table 2). In Exp. 2, the smallest amounts were found in the flushings from untreated, ovariectomized females and in the flushings from females treated for only 2 days with progesterone and oestradiol. After 4 days of progesterone treatment, the content of both markers in the flushings increased but not significantly $(P>0.05)$. The increase was highly statistically significant in females treated with progesterone and oestradiol to induce full uterine closure $(P<0.01)$. 
Table 1. The mean \pm s.e.m. peak pressures generated during the flushing of the mouse uterus at $300 \mu \mathrm{l} / \mathrm{min}$ for $30 \mathrm{sec}$

\begin{tabular}{lcc}
\multicolumn{1}{c}{ Treatment } & $\begin{array}{c}\text { No. of uterine } \\
\text { horns }\end{array}$ & $\begin{array}{c}\text { Peak pressure } \\
\text { (mmHg) }\end{array}$ \\
\hline (a) Ovariectomized females & & \\
(i) Untreated & 10 & $35 \cdot 0 \pm 2 \cdot 2$ \\
(ii) 100 ng oestradiol-17 7 for 2 days & 10 & $33 \cdot 6 \pm 3 \cdot 4$ \\
(iii) 1 mg progesterone for 4 days & 11 & $76.8 \pm 14.5^{*}$ \\
(iv) 1 mg progesterone + 10 ng oestradiol-17 for 4 days & 10 & $110 \cdot 0 \pm 19 \cdot 7 \dagger$ \\
\hline (b) Intact females & & \\
(i) Day 4 pregnancy & 16 & $42 \cdot 6 \pm 14 \cdot 3$ \\
(ii) Day 5 pregnancy & 12 & $87 \cdot 4 \pm 18 \cdot 4 \ddagger$ \\
\hline
\end{tabular}

Significantly different from values for Groups a(i) and a(ii): ${ }^{*} P<0.05 ; \dagger P<0.01$.

$\ddagger$ Significantly different from Group b(i): $P<0 \cdot 05$.

Table 2. The content of ${ }^{51} \mathrm{Cr}$-labelled EDTA $\left({ }^{51} \mathrm{Cr}\right.$-EDTA) and ${ }^{125} \mathrm{I}$-labelled human serum albumin ( ${ }^{125}$ I-HSA) in mouse uterine flushings

\begin{tabular}{|c|c|c|c|c|}
\hline \multirow[b]{2}{*}{ Experiment } & \multirow[b]{2}{*}{ Treatment } & \multirow{2}{*}{$\begin{array}{l}\text { No. of } \\
\text { uterine } \\
\text { horns }\end{array}$} & \multicolumn{2}{|c|}{ Content of markers } \\
\hline & & & ${ }^{51} \mathrm{Cr}$-EDTA & ${ }^{125}$ I-HSA \\
\hline $\begin{array}{l}2 \text { (ovariectomized, } \\
\text { steroid-treated females) }\end{array}$ & $\begin{array}{l}\text { (i) None } \\
\text { (ii) } 2 \text { days progesterone + oestradiol } \\
\text { (iii) } 4 \text { days progesterone + oestradiol } \\
\text { (iv) } 4 \text { days progesterone only }\end{array}$ & $\begin{array}{r}9 \\
10 \\
10 \\
11\end{array}$ & $\begin{array}{c}48 \pm 12 \\
40 \pm 8 \cdot 1 \\
170 \pm 32^{*} \\
81 \pm 16\end{array}$ & $\begin{array}{c}1.7 \pm 0.6 \\
1 \cdot 8 \pm 0.4 \\
10 \cdot 6 \pm 3 \cdot 4^{*} \\
3 \cdot 3 \pm 0.9\end{array}$ \\
\hline 3 (pregnant females) & $\begin{array}{l}\text { (i) Day 3: rapid, manual flushing } \\
\text { (ii) Day 3: slow controlled flushing } \\
\text { (iii) Day 5: rapid, manual flushing } \\
\text { (iv) Day 5: slow controlled flushing } \\
\text { (v) Ovariectomized on Day } 3+1 \mathrm{mg} \text { medroxy- } \\
\text { progesterone acetate; flushed Day } 10 \\
\text { (vi) as (v), but with } 50 \text { ng oestradiol-177 on Day } 9\end{array}$ & $\begin{array}{r}12 \\
10 \\
12 \\
8 \\
9\end{array}$ & $\begin{array}{l}67 \pm 10 \\
486 \pm 62 \dagger \\
322 \pm 45 \dagger \\
773 \pm 178 \ddagger \\
109 \pm 18 \\
158 \pm 42\end{array}$ & $\begin{aligned} 4 \cdot 4 & \pm 0 \cdot 5 \\
20 & \pm 7 \cdot 0 \S \\
18 & \pm 3 \cdot 8 \dagger \\
29 & \pm 6 \cdot 6 \\
4 \cdot 6 \pm 0 \cdot 5 & \\
11 & \pm 2 \cdot 5 \uparrow\end{aligned}$ \\
\hline
\end{tabular}

The tracers were administered i.v. 30 and $3 \mathrm{~min}$ before flushing (see 'Methods').

Results are in $\mathrm{nl}$ (mean \pm s.e.m.) of interstitial fluid or plasma containing the equivalent amount of tracer.

$* P<0.01$ compared with values for (i), (ii) and (iv) in Exp. 2.

Significant difference in treatment values: $P<0.01$ compared with Treatment $i(\dagger)$ and iii $(\ddagger) ; P<0.05$ compared with Treatment $\mathrm{i}(\S)$ and $\mathrm{v}(\boldsymbol{\Phi})$.

In Exp. 3, the content of the markers was significantly higher after flushing on Day 5 of pregnancy than on Day 3 and slow controlled flushing of the uterus on either day produced considerably greater amounts of both tracers (Table 2). A significant increase in the ${ }^{125}$ I-labelled HSA content of the flushing was also observed after the induction of delayed implantation by oestradiol treatment (Table 2).

\section{Discussion}

The results of this study and that of Martin (1984) suggest that great caution should be exercised in interpreting analyses of mouse uterine flushings. Attempting to force relatively large amounts of fluid through the uterus, particularly at times when the uterine luminal walls are closely apposed, may cause damage to the uterine tissue and result in contamination of the samples collected. A close 
correlation is apparent between the hydrostatic pressures generated during flushing (Exp. 1), the content of plasma and interstitial markers in the flushings (Exp. 2), the degree of histological damage (Martin, 1984) and the extent of uterine closure (Pollard \& Finn, 1972). The highest pressures during flushings were observed under conditions of complete uterine closure and in uteri with early implantation sites (Exp. 1). The high pressures reflect the difficulty of forcing fluid through a uterus in which the lumen has essentially been obliterated by the close apposition of the luminal epithelial walls and direct observation indicated that the pressure fell once the flushing medium had traversed the whole length of the uterus. It should be emphasized that the pressures monitored in the present study were under conditions of relatively slow, controlled flow. During rapid, manual flushing (e.g. Aitken, 1977a; Pratt, 1977; Guise et al., 1981; Hoversland \& Weitlauf, 1982; Martin, 1984) considerably higher and more variable pressures would be expected. Such pressures are presumably responsible for the observed tissue damage (Martin, 1984).

Evidence that samples collected by uterine flushing may be contaminated by non-luminal components comes from a number of sources. In the present study, markers for plasma and interstitial fluid were found in all samples. It seems likely that the presence of the tracers reflects contamination rather than their 'luminal content' for the following reasons: (a) the uterine luminal epithelium presents a very tight barrier to the passage of such tracers (McRae \& Kennedy, 1979). (b) The 3 min circulation time for ${ }^{125}$ I-labelled HSA is insufficient to allow appreciable leakage from the vascular compartment (Sassen et al., 1968). In any case, the variable amounts of ${ }^{125} \mathrm{I}$ labelled HSA do not reflect differences in uterine vascular permeability: there are no significant differences in vascular permeability (as determined by extravascular ${ }^{125}$ I-labelled HSA accumulation $30 \mathrm{~min}$ after i.v. administration) between Days 3 and 5 of pregnancy, or between Days 2 and 4 of progesterone plus oestradiol treatment (S. R. Milligan \& F. M. Mirembe, unpublished observations). (c) The maximal content of the tracers was found under conditions of uterine closure, when the volume of the uterine lumen (if it can be said to exist at all) is minimal. (d) The variable amounts of the tracers found after flushing at different speeds is consistent with variable degrees of leaching of damaged tissue rather than a fixed luminal content. The greater content of the tracers after slow, controlled flushing is consistent with the longer time available for the leaching of the tissues and for the diffusion of the markers into the area of leaching. Additional independent evidence suggesting that contamination of flushings may occur comes from the observation of prominent haemoglobin electrophoretic bands (Aitken, 1977a) and the presence of red blood cells in the uterine lumen after flushing (Martin, 1984). Many of the previous studies employing the flushing technique (Gore-Langton \& Surani, 1976; Aitken, 1977a, b; Pratt, 1977) the samples were collected from the cut end of the uterine horn and this method was also adopted in the present study. Undoubtedly some contamination may arise from this source, but the amount of such contamination would be expected to be similar between the treatments and in the present experiments the uteri were well rinsed to minimize this.

Samples collected by flushing the uterus of the mouse have been reported to be dominated by serum proteins and to show qualitative changes, as well as increased protein content, at implantation and under conditions of uterine closure (Gore-Langton \& Surani, 1976; Aitken 1977a, b; Pratt, 1977). The amounts of protein obtained by luminal flushing are quite variable. Aitken (1977a) reported values of $2 \cdot 3$ and $10 \mu \mathrm{g} / \mathrm{uterine}$ horn on Days 3 and 5 of pregnancy respectively, while Pratt (1977) found values of 16.5 and $27 \mu \mathrm{g} /$ horn on these days. The extent to which the degree of contamination observed in the present study may account for these values is uncertain because of the unknown protein content of mouse uterine interstitial fluid. Assuming a plasma protein concentration of $55 \mathrm{mg} / \mathrm{ml}$ and a probably conservative estimate of interstitial fluid protein concentration of half this value, the degree of contamination in this study would produce $2 \cdot 1$ and $9 \cdot 7 \mu \mathrm{g}$ protein/horn on Days 3 and 5 of pregnancy. Such contamination would account for almost all the protein observed by Aitken (1977a) and 12-30\% of that reported by Pratt (1977). It must be questioned, therefore, whether qualitative and quantitative changes in the proteins detected by flushing really reflect changes in the uterine lumen: they are also consistent with variable degrees of 
tissue damage and contamination of the samples. Very few authors have reported histological examination of the uteri after flushing. Although Gore-Langton \& Surani (1976) reported that the luminal epithelium remained intact after flushing in their study, this does not preclude less obvious tissue damage which might result in contamination. This caution may also be applicable to flushings of uteri from other species exhibiting 'closure' in early pregnancy (e.g. rat: Mayer, Nilsson \& Reinius, 1967; hamster: Surani \& Burling, 1979).

The results of the present study and that of Martin (1984) may also be relevant to experiments involving the intraluminal administration of materials. A number of studies (e.g. Pratt, 1977; Fishel, 1979, 1980) have employed the intraluminal injection of ${ }^{3} \mathrm{H}$-amino acids followed some hours later by flushing. The radiolabelled proteins in the flushings are assumed to represent uterine secretions. The possibility now arises, however, that the intraluminal injection may introduce labelled amino acids into the subepithelial tissues and that the subsequent flushing may induce cellular and tissue damage and 'release' labelled proteins that are not normally secreted. Similar uncertainties arise when considering the effectiveness and action of intraluminally administered substances (e.g. cholera toxin: Rankin, Ledford \& Baggett, 1977; lectins, A23187: Buxton \& Murdoch, 1982): any simple interpretation of the results of such studies is complicated by the possibility that the method of introduction into the lumen may damage uterine tissues and provide a route for direct access to subepithelial tissues.

S.R.M. is grateful to Simon Devine for technical assistance and the Wellcome Trust for financial support of this project.

\section{References}

Aitken, R.J. (1977a) Changes in the protein content of mouse uterine flushings during normal pregnancy and delayed implantation, and after ovariectomy and oestradiol administration. J. Reprod. Fert. 50, 29-36.

Aitken, R.J. (1977b) The protein content of mouse uterine fiushings during pseudopregnancy. $J$. Reprod. Fert. 50, 191-192.

Buxton, L.E. \& Murdoch, R.N. (1982) Lectins, calcium ionophore A23187 and peanut oil as deciduogenic agents in the uterus of pseudopregnant mice: effects of tranylcypromine, indomethacin, iproniazid and propanolol. Aust. J. biol. Sci. 35, 63-72.

Fishel, S.B. (1979) Analysis of mouse uterine proteins at pro-oestrus, during early pregnancy and after administration of exogenous steroids. J. Reprod. Fert. 55, 91-100.

Fishel, S.B. (1980) Radiolabelled uterine proteins during early pregnancy and pseudopregnancy in mice after unilateral ovariectomy and superovulation. $J$. Reprod. Fert. 59, 473-478.

Gore-Langton, R.E. \& Surani, M.A.H. (1976) Uterine luminal proteins of mice. $J$. Reprod. Fert. 46, 271274.

Guise, M.B., Gwazdauskas, F.C. \& Lineweaver, J.A. (1981) Effects of lyophilisation and freezing on the analysis of mouse uterine lumenal fluids and qualitative aspects of secretions from breeder and nonbreeder mice. Proc. Soc. exp. Biol. Med. 137, 290-292.

Hoversland, R.C. \& Weitlauf, H.M. (1982) In-vitro zonalytic activity in uterine fluid from ovariectomized mice treated with oestradiol- $17 \beta$ and progesterone. $J$. Reprod. Fert. 64, 223-226.
Humphrey, K.W. (1967) The induction of implantation in the mouse after ovariectomy. Steroids 10, 591-600.

Li, J.C.R. (1957) Introduction to Statistical Inference. Edward Brothers, Ann Arbor.

McRae, A.C. \& Kennedy, T.G. (1979) Evidence for a permeability barrier between blood and uterine luminal fluid in estrogen-treated, immature rats. Biol. Reprod. 20, 919-923.

Martin, L. (1980) What roles are fulfilled by uterine epithelial components in implantation? In Progress in Reproductive Biology, Vol. 7, pp. 54-69. Eds F. Leroy, C. A. Finn, A. Psychoyos \& P. O. Hubinot. Karger, Basel.

Martin, L. (1984) On the source of uterine luminal fluid proteins in the mouse. J. Reprod. Fert. 71, 73-80.

Martin, L. \& Finn, C.A. (1970) The effects of an intrauterine device on uterine cell division and epithelial morphology during early pregnancy in the mouse. $J$. Endocr. 48, 347-354.

Martin, L. \& Finn, C.A. (1979) Varying effects of an IUD on decidualization in mice. J. Reprod. Fert. 55, 125133.

Mayer, G., Nilsson, O. \& Reinius, S. (1967) Cell membrane changes of uterine epithelium and trophoblast during blastocyst attachment in the rat. $Z$. Anat. EntwGesch. 126, 43-48.

Milligan, S.R. \& Lytton, F.D.C. (1983) Changes in prostaglandin levels in the sensitized and nonsensitized uterus of the mouse after intrauterine instillation of oil or saline. J. Reprod. Fert. 67, 373377.

Pollard, R.M. \& Finn, C.A. (1972) Ultrastructure of the 
uterine epithelium during the hormonal induction of sensitivity and insensitivity to a decidual stimulus in the mouse. J. Endocr. 55, 293-298.

Pratt, H.P.M. (1977) Uterine proteins and the activation of embryos from mice during delayed implantation. J. Reprod. Fert. 50, 1-8.

Rankin, J.C., Ledford, B.E. \& Baggett, B. (1977) Early involvement of cyclic nucleotides in the artificially stimulated decidual cell reaction in the mouse uterus. Biol. Reprod. 17, 549-554.
Sassen, A., Reuter, A.M. \& Kennes, F. (1968) Determination of plasma volume in the mouse with screened radiolabelled proteins. Experientia 12, 1203-1204.

Surani, M.A.H. \& Burling, A. (1979) Uterine growth and differentiation in response to ovarian steroids in the hamster. Biol. Reprod. 21, 657-666.

Yoshinaga, K. \& Adams, C.E. (1966) Delayed implantation in the spayed, progesterone treated adult mouse. J. Reprod. Fert. 12, 593-595.

Received 27 July 1983 